УДК 32

DOI $10.21661 / \mathrm{r}-467865$

\title{
В.В. Кривочеев
}

\section{ПАТРИОТИЗМ В РОССИИ}

Аннотация: в работе представлен анализ развития системы современного воспитания патриотизма среди молодежи. Дана характеристика основным аспектам работы в подростковой среде. Выделены плюсы и минусы современных патриотических программ, раскрывается роль патриотического воспитания в современном российском обществе. Выделена роль школь и семьи как основополагающих принципов становления нравственно-патриотического сознания ребенка. Отмечается, что формирование гражданской позищии возможно только на основе укоренивщихся в сознании личности чувств долга и ответственности.

Ключевые слова: патриотизм, урок, история, память.

\section{V.V. Krivosheev}

\section{PATRIOTISM IN RUSSIA}

Abstract: the paper presents an analysis of the development of the system of modern upbringing of patriotism among young people. The characteristic of the main aspects of work in the teenage environment is given. The advantages and disadvantages of modern patriotic programs are singled out, the role of patriotic education in modern Russian society is revealed. The role of school and family as the basic principles of the formation of the moral-patriotic consciousness of the child is singled out. It is noted that the formation of a civic position is possible only on the basis of feelings of duty and responsibility rooted in the mind of the individual.

Keywords: patriotism, lesson, history, memory.

Актуальность темы исследования. Выдающийся русский историк B.О. Ключевский писал, что «история учит даже тех, кто у неё не учится, она их проучивает за невежество и пренебрежение» [4]. К этому известному афоризму хочется добавить, что история работает против тех, кто ее не знает. Она нередко 
выступает средством борьбы разных политических сил, пропаганды и насаждения требуемых стереотипов общественного сознания. В современном российском социуме историческое наследие наших предков используют как основу формирования патриотических ценностей. Однако этот, казалось бы, позитивный процесс различные политические силы используют как лозунг, под которым можно без особых усилий прийти к власти. В таком случае, речь идет о псевдопатриотизме, а следовательно, и о псевдоистории. Тем самым теряется настоящее наследие, то, что мы привыкли считать историей своего Отечества. Цель работы состоит в анализе патриотического воспитания в современном российском обществе.

В современной России проблема патриотического воспитания граждан приобрела статус масштабной государственной задачи. Цель разноплановых проектов по патриотическому воспитанию - формирование чувства гордости за свою Родину, чувства любви и уважения к ней, ее давним традициям и истокам. При этом очевидно, что патриотизм и история - это два неразрывных понятия.

Современная система патриотического воспитания основывается на государственной программе «Патриотическое воспитание граждан Российской Федерации» [6] Программа представляет собой объединенный замыслом и целью комплекс нормативно-правовых, организационных, научно-исследовательских и методических мероприятий, призванных обеспечить решение основных задач в области патриотического воспитания. Программа начала действовать с 2001 года. В 2001-2015 годах реализованы 3 государственные программы патриотического воспитания. Патриотическое воспитание представляет собой систематическую и целенаправленную деятельность органов государственной власти, институтов гражданского общества и семьи по формированию у граждан высокого патриотического сознания, чувства верности своему Отечеству, готовности к выполнению гражданского долга и конституционных обязанностей по защите интересов Родины. Реализация этой программы предполагает создание различных клубов, лагерей, центров военно-патриотического воспитания, массовое привлечение подрастающего поколения к занятиям физической культурой и 
спортом, реализация в образовательных учреждениях программ и мероприятий по патриотическому воспитанию.

Основную идею программы поддерживали многие политические лидеры, в том числе, лидер партии ЛДПР В.Ф. Жириновский: «Начинать с того, чтобы мы все с детского сада понимали, что мы граждане вот этой страны нашей. Что это не просто земля, где живут китайцы, африканцы, монголы - начинать надо с того, что это земля, где живут граждане России, что мы одна большая семья. Нас объединит территория, которую нам оставили предки, 1/6 часть суши, от Камчатки до Калининграда, от Мурманска до Махачкалы. Это наша страна, это наши огромные богатства, лес, тайга, нефть, смотрите, сколько золота сегодня нашли в Иркутской области! Мы должны показать, что мы ходим по земле, за которую пролили море крови» [1].

В то же время, нельзя говорить и о высокой эффективности реализации программы. Если физическому воспитанию действительно уделяется большое внимание, то проблема формирования духовно-нравственных ценностей учащихся пока стоит наиболее остро. Мероприятия патриотической направленности широко пропагандируются, но статистика по желающим покинуть страну в обозримом будущем никак не меняется, а только растет. Безусловно, тут большую роль играет внутренняя политика правительства, уровень жизни каждого отдельно взятого человека, рост его доходов и благосостояния. Но и проявления духовного кризиса общества очевидны.

По данным медиахолдинга РБК, оказалось, что за последние годы подростки стали чаще употреблять алкоголь и наркотики (в т.ч. тяжелые), а также совершать преступления, проявляя девиантное поведение. Таким образом, в России пока не удалось построить эффективную систему борьбы с подростковой преступностью. С 2006 по 2010гг. доля законопослушных подростков снизилась с $32 \%$ до 15\% от общего числа опрошенных, а количество малолетних хулиганов и дебоширов увеличилось с 58\% до 69\%. Если восемь лет назад к трудным можно было причислить лишь каждого десятого подростка, то сегодня - каждого шестого (16\%). Почти половина старшеклассников имеют опыт участия в драках, 
43\% знакомы с понятием «вандализм», а каждый пятый совершал мелкие кражи из магазинов [2]. Социологи заметили, что у современных подростков, причисляющих себя к субкультурам, ярко выражено стремление к риску. Анализируя причины, побудившие старшеклассников вступать в драки, они указали несколько мотивов, главный из которых - желание защитить собственное «я». Так, 43\% респондентов мстили за оскорбления, 39\% защищались от нападавших, 34\% встали на защиту друга или подруги, а 19\% вступали в «войны между группировками» [2]

Подобные факты заставляют задуматься о том, насколько эффективно работают государственные программы по патриотическому воспитанию в школах. И это несмотря на то, что воспитательный потенциал школы огромен. По статистике, современный ребенок только 10-15\% своего времени проводит в семье, остальное - в школе, учреждениях дополнительного образования и со сверстниками. Соответственно, каждая школа может реализовать собственную программу патриотического воспитания, которая будет включать:

1) духовно-нравственное воспитание, представляющее собой формирование таких качеств, как честность, добросовестность, уважение к семье и старшему поколению, любовь к Родине;

2) культурно-историческое воспитание, которое включает воспитание у учащихся любви к своей «малой» Родине, формирование чувства национальной гордости, национального самосознания и толерантности;

3) военно-патриотическое воспитание, ориентированное на изучение истории России, ознакомление с Днями боевой славы, сохранение воинских традиций, почитание ветеранов войны и труда.

Следует учитывать, что государство и школа не смогут сформировать патриотические убеждения подрастающего поколения без участия семьи. Учителя должны проводить соответствующую работу и с родителями, вовлекая их в процесс формирования патриотического сознания детей. От убеждений, моральных норм, ценностей и интересов родителей в большей степени зависит, какими вырастут их дети. Дома закладываются нравственные и моральные базисы, 
начинают формироваться привычки, нормы и ценности. В семьях, где уважается преемственность традиций, историческая память, есть реликвии старших поколений, у детей формируется высокое патриотическое чувство. Очень важно, чтобы родители совершали с детьми прогулки к историческим памятникам, походы в музеи, давали возможность слушать воспоминания своих родственников о недавнем прошлом. По словам Д.В. Крупницкого, «формирование образа Родины в школьном возрасте имеет ярко выраженную мировоззренческую направленность и выступает как активный познавательный процесс. Знания и представления о своей стране, её культуре, истории и природе являются важнейшим условием формирования отношения учащихся к Родине и впоследствии, при определённых условиях воспитания и обучения, составляют основу убеждений и мировоззрения детей» [5].

В целом, гражданско-патриотическое воспитание в современных условиях это целенаправленный процесс подготовки подрастающего поколения к функционированию в условиях демократического общества, к реализации прав и обязанностей, а также укрепления ответственности за свой политический, нравственный и правовой выбор. История - это то, на чем должно базироваться воспитание патриотизма и гражданственности. На примере реальных исторических событий есть реальная возможность сравнить патриотические настроения предшествующих поколений и современного российского социума. К сожалению, это сравнение далеко не в пользу наших современников.

Подрастающее поколение России должно дать новый импульс к развитию страны. Это должны быть люди, убежденные в величии и нерушимости нашего государства, хотя бы потому, что история это не раз доказывала. Любой из наших прославленных героев может стать образцом для подражания. Не голливудские актеры или музыканты, а наши генералы, маршалы, врачи, ученые, те, на кого стоит равняться. Именно эти люди своими делами вписали свои имена в мировую историю и прославили свое Отечество. 


\section{Список литературы}

1. Жириновский В. Для воспитания патриотизма не нужна идеология [Электронный pecypc]. - Режим доступа: https://ldpr.ru/events/Vladimir_ Zhirinovsky_To_foster_patriotism_does_not_need_an_ideology/

2. В России каждый шестой подросток является трудным [Электронный ресурс]. - Режим доступа: http://www.rbc.ru/society/01/06/2012/5703f8619a $7947 \mathrm{ac} 81 \mathrm{a} 68908$

3. В Электростали восьмиклассник зарезал школьного охранника [Электронный ресурс]. - Режим доступа: http://www.rbc.ru/society/20/10/2014/544557f0 cbb20f669fb85e51

4. Ключевский В.О. Русская история. Полный курс лекций [Электронный pecypc]. - Режим доступа: https://books.google.ru/books?id=J6kFe8jty3MC\&pg

5. Любовь к Родине начинается с семьи [Электронный ресурс]. - Режим доступа: https://nsportal.ru/blog/nachalnaya-shkola/all/2013/05/04/lyubov-k-rodinenachinaetsya-s-semi

6. Патриотическое воспитание граждан Российской Федерации [Электронный pecypc]. - Режим доступа: http:/static.government.ru/media/files/ 8qqYUwwzHUxzVkH1jsKAErrx2dE4q0ws.pdf

7. Старшеклассник в Москве застрелил учителя и полицейского [Электронный ресурс].- Режим доступа: http://www.bbc.com/russian/russia/2014/02/ 140203_moscow_school_hostages

\section{References}

1. Zhirinovsky V. To develop patriotism, ideology is not needed [Electronic resource]. - Access mode: https://ldpr.ru/events/Vladimir_Zhirinovsky_To_foster_patriotism_does_not_need_an_ideology/

2. In Russia every sixth teenager is difficult [Electronic resource]. - Access mode: http://www.rbc.ru/society/01/06/2012/5703f8619a7947ac81a68908

3. In Electrostal, an eighth-grade student stabbed a school guard [Electronic resource]. - Access mode: http://www.rbc.ru/society/20/10/2014/544557f 0cbb20f669fb85e51 
4. Kliuchevskiy V.O. Russian history. Full course of lectures [Electronic resource]. - Access mode: https://books.google.com/books?id=J6kFe8jty3MC\&pg

5. Love for the Motherland begins with the family [Electronic resource]. - Access mode: https://nsportal.ru/blog/nachalnaya-shkola/all/2013/05/04/lyubov-k-rodine-nachinaetsya-s-semi

6. Patriotic education of citizens of the Russian Federation [Electronic resource]. - Access mode: http://static.government.ru/media/files/8qqYUwwz HUxzVkH1jsKAErrx2dE4q0ws.pdf

7. High school student in Moscow shot a teacher and a policeman [Electronic resource]. - Access mode: http://www.bbc.com/russian/russia/2014/02/140203_moscow_school_hostages

Кривошеев Владимир Вячеславович - студент ФГБОУ ВО «Мордовский государственный педагогический институт им. М.Е. Евсевьева», Россия, Саранск.

Krivosheev Vladimir Viacheslavovich - student at Mordovian State Pedagogical Institute named after M.E. Evseviev, Russia, Saransk. 